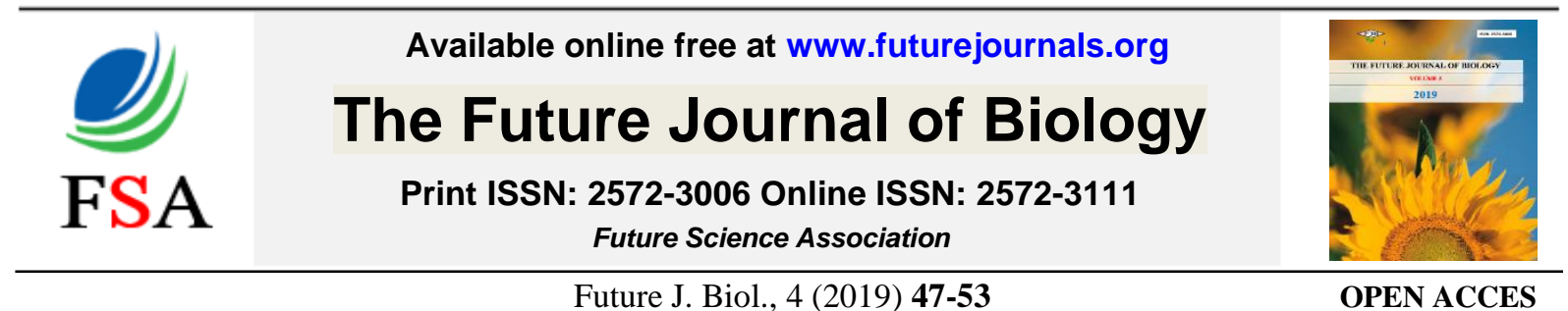

DOI: $10.37229 /$ fsa.fjb.2019.12.11

\title{
TEFFEC OF AMINO ACIDS ON GROWTH AND FLOWERING OF Rosa hybrid L. PLANT GROWING IN NUTRIENT FILM TECHNIQUE AND SOLID SUBSTRATE SOILLESS CULTURE
}

\author{
Walid S. Nosir ${ }^{*}$ and Ramy G. El-Kinany ${ }^{2}$ \\ ${ }^{1}$ Hort. Dept., Fac. Agric., Zagazig Univ., Egypt. \\ ${ }^{2}$ Hort. Dept., Fac. Agric., Damanhour University, Damanhour, El-Beheira, PO Box 59, Egypt. \\ "Corresponding author: w.nosir@gmail.com Received: 10 Nov. 2019 ; Accepted: 11 Dec. 2019
}

\begin{abstract}
Rosa hybrida (cv. Red Dino) was grown at the experimental site of the Hort. Dept., Fac. Agric., Zagazig University, Egypt, during the two seasons of 2017 and 2018. In order to estimate the effect of different amino acid types (glutamine, methionine, phenylalanine and proline), soilless culture methods (nutrient film technique and solid substrate culture) and their combination treatments on growth and flowering of rose plant. These experiments were designed as a split-plot in complete randomized block design with three replicates. The results showed that in most cases phenylalanine acid gave the highest values of growth parameters (plant height, number and weight of leaves, leaf length and width as well as root length) compared to the other amino acid types under study. The same trend was obtained concerning flowering parameters (flowers number, weight and diameter per plant, flower stalk length as well as vase life of cut flowers) during both seasons. The solid substrate culture (SSC) in most cases gave correspondingly higher values of above mentioned parameters (except that of flowering date and flowers vase life) than the nutrient film technique (NFT). Total chlorophyll content (SPAD) was significantly increased with SSC compared to NFT. The best combination treatment, from the productive point of view, was treating plants with phenylalanine acid at $200 \mathrm{ppm}$ and culturing in solid substrate soilless culture (mixture of granulated sand and peat).
\end{abstract}

Key words: Rose, Soilless culture, Amino acids, Growth, Flowering, Chlorophyll

\section{INTRODUCTION}

Rose (Rosa hybrida L.) is the most important member of the Family Rosacea, which contains 200 species and more than 18,000 cultivars (Gudin, 2000), grown as ornamental plant around the world. It is one of the leading cut flowers and ranks among the top ten cut flowers of the world. Cut rose flowers play a remarkable role in interior decoration and add charm to different social and cultural ceremonies. Millions of rose shrubs are planted in garden or pots and billions of rose cut flowers are sold annually all over the world (Khosh-Khui and Teixeira da Silva, 2006).

Soilless culture system represents a valid alternative to conventional cultivation techniques due to the full control of the inputs that provides, and it is a good technique to grow rose offering guarantees of quality to the market (Nicola et al.,
2005). It allows to produce clean material at harvest, and consequently to reduce many washing treatments. Nutrient film technique (NFT) can be utilized to overcome soil problems where, plants grow in the solution of nutrient directly, so it does not need any disinfection. NFT had an enormous latent potential for agriculture production areas where soil has a disease and pest problems (Burrage, 1992). Abou-Hadid et al. (1989) indicated that under Egyptian conditions, NFT produced higher yield in shorter time when compared with traditional cultivation. In addition, the cost of production by the NFT is similarly to the soil grown plants.

Davies (1982) reported that amino acids as organic nitrogenous compounds are the building blocks in the synthesis of protein components. Amino acids (AA) are particularly important for cell 
growth stimulation. They act as buffers which help to maintain favorable $\mathrm{pH}$ value in the plant cell, since they include both acid and basic groups. The regulatory effect of amino acids on growth could be explained by the theory that some amino acids like phenylalanine (Phe) can affect development through their influence on gibberellins biosynthesis and plant growth (Walter and Nawacke, 1978).

Evidently, the glutamate absorb by the cells faster than it is metabolized, as the glutamate eventually is found in glutamine (Gln), protein and glutathione (El-Ghamry et al., 2009). Phenylalanine and proline are a proteogenic amino acids and accumulates under stress and non-stress conditions as a beneficial solute in plants. Recent discoveries point out that proline plays an important role in plant growth and differentiation across life cycle (Paciorek et al., 2005). Proline may also act as a signaling molecule or regulatory to activate a variety of responses (Maggio et al., 2002). L-methionine considered as a precursor of a significant number of essential biomolecules such as cofactors, vitamins and polyamine (Paciorek et al., 2005). Previous studies have showed an association of L-methionine with the biosynthesis of growth regulating substances such as brassinosteroids, cytokinins and auxins in plants (El-Awadi et al., 2011 and Yong et al., 2014).

The aim of the present study is to evaluate the performance of different amino acids on the growth and flowering of rose plants in different soilless culture systems.

\section{MATERIALS AND METHOD}

This study was carried out in the experimental site of the Horticulture Department, Faculty of Agriculture, Zagazig University, Egypt, during the two consecutive seasons of 2017 and 2018 aiming to evaluate the effect of different amino acid types (control, glutamine, methionine, phenylalanine and proline), soilless culture methods (nutrient film technique and solid substrate culture) and their combination treatments on growth and flowering of rose (Rosa hybrida) plant.

\section{Plant material and Growth conditions}

Rose (cv. Red Dino) rooted seedlings, 15 month old were planted in the nutrient film technique (NFT) or solid substrate culture $(\mathrm{SSC})$ on $17^{\text {th }}$ February each season under polyethylene greenhouse conditions. The composition of the nutrient solution was recorded in Table 1.
Table 1. Chemical composition of the nutrient solution

\begin{tabular}{ccccccc}
\hline \multicolumn{7}{c}{ Macronutrients $\left(\mathrm{mol} \mathrm{l}^{-1}\right)$} \\
\hline $\mathbf{N}$ & $\mathbf{P}$ & $\mathbf{K}$ & $\mathbf{C a}$ & $\mathbf{M g}$ & $\mathbf{S}$ \\
\hline 6.1 & 0.5 & 2.6 & 2.0 & 1.6 & 1.3 \\
\hline \multicolumn{7}{c}{ Micronutrients $\left(\mu \mathrm{mol} \mathrm{l}^{-\mathbf{1}}\right)$} \\
\hline $\mathbf{F e}$ & $\mathbf{C u}$ & $\mathbf{M n}$ & $\mathbf{Z n}$ & $\mathbf{B}$ & $\mathbf{M o}$ & $\mathbf{C l}$ \\
\hline 45.0 & 20.0 & 25.0 & 38.0 & 12.0 & 1.0 & 1.0 \\
\hline
\end{tabular}

The nutrient solution used was GHE Floragro (ProGrow Co, UK); pH and electrical conductivity (EC) were adjusted to 7 and $2.5 \mathrm{~S} \bullet \mathrm{m}-1$, respectively. The solution was pumped continuously at a flow rate of $120 \mathrm{lhr}-1$. The nutrient solution reservoir was a 1001 black plastic tank, connected directly to the pipes feeding the plants. A pump (MaxiJet, Mj1000, Aqua culture, UK) with plastic coatings was used to avoid metal contamination due to salt corrosion. The nutrient solution was collected in a 501 black plastic tank and re-cycled by the pump. Nutrient solution was replaced at 14-day intervals. The system was maintained under glasshouse conditions. Seedlings were planted without any substrates around root system.

Plants were grown under a temperaturecontrolled polyethylene greenhouse. Greenhouse temperature was $22^{\circ} \mathrm{C}$; humidity was adjusted to be $70 \%$; and day light was $12 \mathrm{~h}$ in spring and 8 hours in autumn. The NFT equipment consist of rigid PVC gullies (each $12 \mathrm{~cm}$ width, $10 \mathrm{~cm}$ deep and $300 \mathrm{~cm}$ long), with $1 \%$ slope. The gullies were at $70 \mathrm{~cm}$ above ground level and each gully was fed by a separate 221 plastic reservoir tank containing the nutrient solution (NS). Continuous circulation (3 1 $\min ^{-1}$ ) of the NS was provided by a submerged pump into each reservoir tank. The volume of NS in each tank was constantly monitored and it was completely replaced at weekly. No aeration system was used in this experiment. The solid substrate culture (SSC) was stablished by mixing of granulated sand (size 3-7 mm) with peat (80: 20 $\mathrm{v} / \mathrm{v})$, respectively, in plastic pots $(30 \mathrm{~cm}$ diameter and 51 volume). The plants were maintained on concrete benches with a drip irrigation system in open system soilless culture.

Four water soluble amino acids viz., Glutamine (Gln), Methionine (Met), Phenylalanine (Phe) and Proline (Pro) at $200 \mathrm{ppm}$ concentration of each one, which were obtained as Special Grade Chemical form Sigma, USA as well as distilled water as control were applied as a foliar spray (leaves and 
stem) of rose seedlings two times a week on both soilless culture methods.

\section{Experimental design}

These treatments were distributed in a-split plot design with three replications. The soilless culture methods were randomly distributed in the main plots, while amino acid types were randomly distributed in the sub plots. All rose plants in each soilless culture methods received normal agricultural practices whenever they needed.

\section{Data recorded}

After 10 weeks (70 days) of amino acids applications the plant height $(\mathrm{cm})$, number and fresh weight $(\mathrm{g})$ of leaves, leaf length and width $(\mathrm{mm})$ as well as root length (cm) of Rosa hybrida were measured. The days till flowering were recorded. Total number of produced flowers from the beginning of harvest period till the end of season for each treatment was determined. Also, average fresh weight of flower/plant $(\mathrm{g})$, flower stalk length $(\mathrm{cm})$ and flower diameter $(\mathrm{cm})$ were recorded. Three cut flowers from each treatment were placed in jar (500 $\mathrm{ml}$ ) containing $250 \mathrm{ml}$ of distilled water to determine the vase life (days). In addition, total chlorophyll content of leaf was determined by using SPAD- 502 meter (Markwell et al., 1995).

\section{Statistical Analysis}

All collected data were subjected to analysis of variance by using MSTAT-C Statistical Software Package (Analytical Software, 2008). Differences between means were compared by using the least significant difference (LSD) test at $\mathrm{P} \leq 0.05$ as reported by Gomez and Gomez (1984).

\section{RESULTS AND DISCUSSION}

\section{Plant growth parameters}

Data presented in Tables 2 and 3 reveal that, the application of different amino acid types significantly increased vegetative growth parameters of Rosa hybrida compared to control (sprayed with distilled water) in the first and second seasons. Moreover, the tallest plant was observed when plants were treated with phenylalanine at $200 \mathrm{ppm}$ compared to the other ones under study. Phenylalanine acid followed by proline acid significantly increased leaf number/plant, leaf fresh weight/plant, leaf length and width as well as root length compared to the other amino acids under study during both seasons.

Solid substrate culture was more effective in terms of overall vegetative studied parameters compared to nutrient film technique (Tables 2 and 3 ). In the other words, plant height, number and fresh weight of leaves as well as leaf length and width of Rosa hybrida were significantly increased by using solid substrate culture compared to the other one under study during both seasons. While, longer roots were observed with NFT compared to SSC soilless culture during both seasons (Table 3).

In both seasons, plant height, number and fresh weight of leaves, leaf length and width as well as root length of Rosa hybrida were higher with all combination treatments between SSC and different amino acids compared to the combination between NFT and with or without amino acids foliar spray in both seasons (Tables 2 and 3). Also, the combination between solid substrate culture and phenylalanine acid (200 ppm) significantly increased all vegetative growth characters of rose plant (except in the case of root length) comparing with the other ones under study, in most cases, during the two seasons.

Consulting the above mentioned results (Tables 2 and 3), foliar application of different amino acids types under study resulted in significant increases in growth parameters compared with distilled water foliar application (control). This result is in line with those obtained on gerbera (Mahdi and Saeed, 2019). Also, Khan et al. (2019) indicated that plant growth of lettuce significantly improved by applying amino acids, which can, therefore, improves hydroponic production of lettuce plants. The increase in the growth parameters due to spraying phenylalanine may be related to its role in protein building and will perform a number of additional functions in storage of nitrogen, transport and regulating metabolism (Davies, 1982). In addition, Nicola et al. (2005) found that rocket (Eruca sativa) grown in traditional culture had $36.5 \%$ more of dry weight and $41.5 \%$ more of dry matter content than plants grown in soilless culture one, respectively.

Moreover, as mentioned above, both soilless culture methods and all amino acid types (each alone) increased rose growth parameters, in turn; they together might maximize their effects leading to taller plants as well as more and heaviest leaves. 
Table 2. Effect of amino acid type (A), soilless culture method (S) and their combination treatments $(\mathrm{A} \times \mathrm{S})$ on plant height $(\mathrm{cm})$, number of leaves /plant and leaves fresh weight/plant (g) of Rosa hybrida during 2017 and 2018 seasons

\begin{tabular}{|c|c|c|c|c|c|c|}
\hline \multirow{3}{*}{$\begin{array}{c}\text { Amino acid type } \\
\text { (A) }\end{array}$} & \multicolumn{6}{|c|}{ Soilless culture method $(\mathrm{S})$} \\
\hline & \multicolumn{2}{|c|}{2017 season } & \multirow{2}{*}{ Means (A) } & \multicolumn{2}{|c|}{2018 season } & \multirow{2}{*}{ Means (A) } \\
\hline & NFT $*$ & SSC** & & NFT $*$ & $\mathrm{SSC}^{* *}$ & \\
\hline & \multicolumn{6}{|c|}{ Plant height (cm) } \\
\hline Control & 58.00 & 64.33 & 61.17 & 59.67 & 67.00 & 63.33 \\
\hline Glutamine & 66.33 & 68.67 & 67.50 & 67.67 & 69.67 & 68.67 \\
\hline Methionine & 63.00 & 68.00 & 65.50 & 64.67 & 67.67 & 66.17 \\
\hline Phenylalanine & 71.00 & 76.33 & 73.67 & 74.00 & 79.00 & 76.50 \\
\hline Proline & 67.67 & 70.33 & 69.00 & 70.33 & 71.17 & 71.17 \\
\hline Means (S) & 65.20 & 69.53 & & 67.27 & 71.07 & \\
\hline \multirow[t]{2}{*}{ LSD at $5 \%$} & $S=1.60$ & $A=1.61$ & $\mathrm{AS}=\mathbf{2 . 4 8}$ & $S=1.49$ & $A=1.37$ & $\mathrm{AS}=\mathbf{2 . 1 8}$ \\
\hline & \multicolumn{6}{|c|}{ Number of leaves/ plants } \\
\hline Control & 6.33 & 7.67 & 7.00 & 7.00 & 7.33 & 7.17 \\
\hline Glutamine & 7.00 & 9.00 & 8.00 & 7.67 & 9.67 & 8.67 \\
\hline Methionine & 7.33 & 8.33 & 7.83 & 7.67 & 9.00 & 8.33 \\
\hline Phenylalanine & 9.33 & 13.00 & 11.17 & 10.67 & 13.33 & 12.00 \\
\hline Proline & 8.67 & 11.00 & 9.83 & 9.33 & 11.67 & 10.50 \\
\hline Means (S) & 7.73 & 9.80 & & 8.47 & 10.20 & \\
\hline \multirow[t]{2}{*}{ LSD at $5 \%$} & $S=0.29$ & $A=0.60$ & $\mathbf{A S}=\mathbf{0 . 8 0}$ & $S=1.08$ & $A=1.15$ & $\mathbf{A S}=\mathbf{1 . 7 0}$ \\
\hline & \multicolumn{6}{|c|}{ Fresh weight of leaves/ plant (g) } \\
\hline Control & 6.54 & 7.49 & 7.02 & 6.54 & 7.85 & 7.19 \\
\hline Glutamine & 8.23 & 9.08 & 8.66 & 8.21 & 8.73 & 8.47 \\
\hline Methionine & 7.41 & 7.43 & 7.42 & 7.27 & 7.93 & 7.60 \\
\hline Phenylalanine & 10.72 & 12.40 & 11.56 & 11.10 & 13.81 & 12.46 \\
\hline Proline & 10.36 & 10.74 & 10.55 & 10.70 & 12.12 & 11.41 \\
\hline Means (S) & 8.65 & 9.43 & & 8.76 & 10.09 & \\
\hline LSD at $5 \%$ & $S=0.71$ & $A=0.61$ & $\mathbf{A S}=\mathbf{1 . 0 0}$ & $S=0.46$ & $\mathrm{~A}=\mathbf{0 . 5 0}$ & $\mathrm{AS}=\mathbf{0 . 7 5}$ \\
\hline
\end{tabular}

* NFT $=$ Nutrient film technique and $* * \mathbf{S S C}=$ Solid substrate culture

Table 3. Effect of amino acid type (A), soilless culture method (S) and their combination treatments $(\mathrm{A} \times \mathrm{S})$ on leaf length $(\mathrm{mm})$, leaf width $(\mathrm{mm})$ and root length $(\mathrm{cm})$ of Rosa hybrida during 2017 and 2018 seasons

\begin{tabular}{|c|c|c|c|c|c|c|}
\hline \multirow{3}{*}{$\begin{array}{c}\text { Amino acid type } \\
\text { (A) }\end{array}$} & \multicolumn{6}{|c|}{ Soilless culture method (S) } \\
\hline & \multicolumn{2}{|c|}{2017 season } & \multirow{2}{*}{ Means (A) } & \multicolumn{2}{|c|}{2018 season } & \multirow{2}{*}{ Means (A) } \\
\hline & NFT * & $\mathrm{SSC}^{* *}$ & & NFT * & SSC*** & \\
\hline & \multicolumn{6}{|c|}{ Leaf length $(\mathrm{mm})$} \\
\hline Control & 61.67 & 63.00 & 62.33 & 59.67 & 63.67 & 61.67 \\
\hline Glutamine & 63.67 & 67.67 & 65.67 & 67.00 & 69.00 & 68.00 \\
\hline Methionine & 62.67 & 64.67 & 63.67 & 64.33 & 65.67 & 65.00 \\
\hline Phenylalanine & 69.00 & 72.00 & 70.50 & 70.33 & 73.33 & 71.67 \\
\hline Proline & 66.67 & 70.33 & 68.50 & 69.33 & 71.67 & 70.50 \\
\hline Means (S) & 64.73 & 67.53 & & 66.07 & 68.67 & \\
\hline \multirow[t]{2}{*}{ LSD at $5 \%$} & $S=0.99$ & $A=0.95$ & $\mathrm{AS}=1.48$ & $S=1.31$ & $A=0.86$ & $\mathrm{AS}=\mathbf{1 . 6 1}$ \\
\hline & \multicolumn{6}{|c|}{ Leaf width (mm) } \\
\hline Control & 26.67 & 28.67 & 27.67 & 25.67 & 29.67 & 27.67 \\
\hline Glutamine & 28.67 & 30.67 & 29.67 & 27.00 & 32.00 & 29.50 \\
\hline Methionine & 27.67 & 31.00 & 29.33 & 28.67 & 32.67 & 30.67 \\
\hline Phenylalanine & 33.00 & 37.00 & 35.00 & 32.00 & 43.00 & 37.50 \\
\hline Proline & 30.33 & 32.33 & 31.33 & 29.67 & 34.33 & 32.00 \\
\hline Means (S) & 29.27 & 31.93 & & 28.60 & 34.33 & \\
\hline \multirow[t]{2}{*}{ LSD at $5 \%$} & $S=1.15$ & $A=0.91$ & $\mathrm{AS}=1.54$ & $S=1.03$ & $A=0.86$ & $\mathrm{AS}=\mathbf{1 . 4 2}$ \\
\hline & \multicolumn{6}{|c|}{ Root length $(\mathrm{cm})$} \\
\hline Control & 14.90 & 14.17 & 14.53 & 15.67 & 13.90 & 14.78 \\
\hline Glutamine & 16.63 & 15.00 & 15.82 & 17.33 & 15.20 & 16.27 \\
\hline Methionine & 17.13 & 14.63 & 15.88 & 16.33 & 15.20 & 15.77 \\
\hline Phenylalanine & 26.83 & 18.50 & 22.67 & 28.50 & 20.00 & 24.25 \\
\hline Proline & 23.00 & 17.27 & 20.13 & 23.83 & 18.07 & 20.95 \\
\hline Means (S) & 19.70 & 15.91 & & 20.33 & 16.47 & \\
\hline LSD at $5 \%$ & $S=0.63$ & $A=0.57$ & $\mathrm{AS}=0.91$ & $S=1.02$ & $A=0.47$ & $\mathrm{AS}=1.11$ \\
\hline
\end{tabular}

$*$ NFT $=$ Nutrient film technique and $* * \mathbf{S S C}=$ Solid substrate culture 


\section{Flowering parameters and chlorophyll content}

Regarding flowering parameters, it is clear from data in Tables 4 and 5 that plants treated with all amino acids reflect significant effect on flowering date, number and fresh weights of flowers/plant, flower stalk length and flower diameter as well as vase life (Table 6) compared to control. The best treatment in this connection was phenylalanine at $200 \mathrm{ppm}$ compared to the other three ones under study during both seasons. it is clear that phenylalanine acid foliar spray significantly decreased the number of days till flowering compared to control and the other amino acid during the two seasons. Total chlorophyll content was significantly increased with phenylalanine treatment compared to control (Table 6).

Generally, fresh weight of flowers/plant, flower stalk length and total chlorophyll content (SPAD unit) of Rosa hybrida were significantly increased by using solid substrate culture compared to NFT during both seasons (Tables 4, 5 and 6). While, least number of days till flowering was observed with plants cultured in SSC compared to NFT soilless culture during both seasons (Table 4).

The combination between both soilless culture methods and spraying with amino acids revealed that the combination which consist of SSC culture and phenylalanine acid gave the highest values of number and fresh weight of flowers/plant, flower stalk length, flower diameter and flowers vase life as well as total chlorophyll content in leaves, while, the lowest values in this regard were noted with NFT culture and without amino acids application (Tables 4, 5 and 6).

Similar results were also found by Mahdi and Saeed (2019) who reported that foliar spray with phenylalanine at $150 \mathrm{mg} . \mathrm{l}^{-1}$ was superior in number of inflorescences, inflorescence diameter, inflorescences stalk length and total chlorophyll content of gerbera plants. Increment in length of flower stalk may be due to the biological effect of these amino acids in stimulating cell division and elongation (Pareek $\boldsymbol{e t}$ al., 2000). Increment in floral parameters due to foliar spray with amino acids are in agreement with those obtained by Abd El-Aziz and Balbaa (2007) on Salvia farinacea, Sewedan and Osman (2014) on Dendranthema grandiflorum and Khattab et al. (2016) on Gladiolus grandiflorum. Furthermore, as mentioned above, both soilless culture methods and different amino acid types (each alone) increased rose flowering traits, in turn; they together might maximize their effects leading to early flowering date as well as more and heaviest flowers.

Table 4. Effect of amino acid type (A), soilless culture method (S) and their combination treatments $(\mathrm{A} \times \mathrm{S})$ on flowering date (days), number of flowers /plant and flower fresh weight/plant (g) of Rosa hybrida during 2017 and 2018 seasons

\begin{tabular}{|c|c|c|c|c|c|c|}
\hline \multirow{3}{*}{$\begin{array}{c}\text { Amino acid type } \\
\text { (A) }\end{array}$} & \multicolumn{6}{|c|}{ Soilless culture method (S) } \\
\hline & \multicolumn{2}{|c|}{2017 season } & \multirow{2}{*}{ Means (A) } & \multicolumn{2}{|c|}{2018 season } & \multirow{2}{*}{ Means (A) } \\
\hline & NFT $*$ & $\mathrm{SSC}^{* *}$ & & NFT * & SSC** & \\
\hline & \multicolumn{6}{|c|}{ Flowering date (days) } \\
\hline Control & 76.67 & 80.33 & 78.50 & 77.33 & 77.67 & 77.50 \\
\hline Glutamine & 67.00 & 64.33 & 65.67 & 65.33 & 66.33 & 65.83 \\
\hline Methionine & 71.67 & 67.67 & 69.67 & 70.33 & 66.67 & 68.50 \\
\hline Phenylalanine & 61.33 & 60.33 & 60.83 & 62.33 & 61.00 & 61.67 \\
\hline Proline & 62.33 & 63.00 & 62.67 & 64.67 & 65.33 & 65.00 \\
\hline Means (S) & 67.80 & 67.13 & & 68.00 & 67.40 & \\
\hline \multirow[t]{2}{*}{ LSD at $5 \%$} & $\mathbf{S}=\mathbf{N} . \mathbf{S}$ & $A=1.04$ & $\mathrm{AS}=1.47$ & $\mathbf{S}=\mathbf{N} . \mathbf{S}$ & $A=1.19$ & $\mathrm{AS}=1.68$ \\
\hline & \multicolumn{6}{|c|}{ Number of flowers/plants } \\
\hline Control & 7.33 & 7.33 & 7.33 & 6.67 & 7.67 & 7.17 \\
\hline Glutamine & 7.33 & 8.33 & 7.83 & 7.67 & 8.33 & 8.00 \\
\hline Methionine & 8.33 & 8.33 & 8.33 & 8.67 & 8.67 & 8.67 \\
\hline Phenylalanine & 9.33 & 10.33 & 9.83 & 9.67 & 10.67 & 10.17 \\
\hline Proline & 8.67 & 9.33 & 9.00 & 7.67 & 9.67 & 9.33 \\
\hline Means (S) & 8.20 & 8.73 & & 8.33 & 9.00 & \\
\hline \multirow[t]{2}{*}{ LSD at $5 \%$} & $S=0.29$ & $A=0.45$ & $\mathrm{AS}=0.62$ & $S=0.76$ & $A=0.69$ & $\mathbf{A S}=\mathbf{1 . 1 0}$ \\
\hline & \multicolumn{6}{|c|}{ Flower fresh weight/plant (g) } \\
\hline Control & 14.70 & 15.53 & 15.12 & 14.60 & 15.83 & 15.22 \\
\hline Glutamine & 15.10 & 17.73 & 16.42 & 15.77 & 18.22 & 16.99 \\
\hline Methionine & 15.47 & 16.47 & 15.97 & 16.03 & 17.30 & 16.67 \\
\hline Phenylalanine & 17.27 & 20.87 & 19.07 & 18.03 & 21.37 & 19.70 \\
\hline Proline & 15.87 & 19.27 & 17.57 & 16.20 & 18.80 & 17.50 \\
\hline Means (S) & 15.68 & 17.97 & & 16.13 & 18.30 & \\
\hline LSD at $5 \%$ & $S=0.45$ & $A=0.62$ & $\mathrm{AS}=\mathbf{0 . 8 8}$ & $S=0.45$ & $A=0.41$ & $\mathrm{AS}=0.66$ \\
\hline
\end{tabular}


Table 5. Effect of amino acid type (A), soilless culture method (S) and their combination treatments $(A \times S)$ on flower stalk length $(\mathrm{cm})$ and flower diameter $(\mathrm{cm})$ of Rosa hybrida during 2017 and 2018 seasons

\begin{tabular}{|c|c|c|c|c|c|c|}
\hline \multirow{3}{*}{$\begin{array}{c}\text { Amino acid type } \\
\text { (A) }\end{array}$} & \multicolumn{6}{|c|}{ Soilless culture method $(S)$} \\
\hline & \multicolumn{2}{|c|}{2017 season } & \multirow{2}{*}{ Means (A) } & \multicolumn{2}{|c|}{2018 season } & \multirow{2}{*}{ Means (A) } \\
\hline & NFT * & SSC** & & NFT * & $\mathrm{SSC}^{* * *}$ & \\
\hline & \multicolumn{6}{|c|}{ Flower stalk length $(\mathrm{cm})$} \\
\hline Control & 32.67 & 34.33 & 33.50 & 30.67 & 35.67 & 33.17 \\
\hline Glutamine & 34.33 & 36.67 & 35.50 & 33.33 & 39.33 & 36.33 \\
\hline Methionine & 35.67 & 35.67 & 35.67 & 37.00 & 39.67 & 38.33 \\
\hline Phenylalanine & 41.00 & 45.67 & 43.33 & 42.33 & 48.33 & 45.33 \\
\hline Proline & 37.67 & 40.67 & 39.17 & 38.67 & 44.00 & 41.33 \\
\hline Means (S) & 36.27 & 38.60 & & 36.40 & 41.40 & \\
\hline \multirow[t]{2}{*}{ LSD at $5 \%$} & $S=0.57$ & $A=0.96$ & $\mathrm{AS}=1.31$ & $S=0.50$ & $A=0.80$ & $\mathrm{AS}=1.11$ \\
\hline & \multicolumn{6}{|c|}{ Flower diameter (cm) } \\
\hline Control & 7.27 & 7.43 & 7.35 & 7.07 & 7.57 & 7.32 \\
\hline Glutamine & 7.63 & 8.10 & 7.87 & 7.53 & 8.08 & 7.81 \\
\hline Methionine & 7.57 & 8.17 & 7.87 & 7.90 & 8.07 & 7.98 \\
\hline Phenylalanine & 8.80 & 9.43 & 9.17 & 9.03 & 9.57 & 9.30 \\
\hline Proline & 8.70 & 8.42 & 8.56 & 8.43 & 8.73 & 8.58 \\
\hline Means (S) & 7.99 & 8.31 & & 7.99 & 8.40 & \\
\hline LSD at $5 \%$ & $S=0.12$ & $\mathrm{~A}=\mathbf{0 . 3 0}$ & $\mathrm{AS}=\mathbf{0 . 4 0}$ & $S=0.69$ & $A=0.38$ & $\mathrm{AS}=\mathbf{0 . 7 8}$ \\
\hline
\end{tabular}

* NFT $=$ Nutrient film technique and $* * \mathbf{S S C}=$ Solid substrate culture

Table 6. Effect of amino acid type (A), soilless culture method (S) and their combination treatments $(\mathrm{A} \times \mathrm{S})$ on vase life (days) and total chlorophyll content (SPAD unit) of Rosa hybrida during 2017 and 2018 seasons

\begin{tabular}{|c|c|c|c|c|c|c|}
\hline \multirow{3}{*}{$\begin{array}{c}\text { Amino acid type } \\
\text { (A) }\end{array}$} & \multicolumn{6}{|c|}{ Soilless culture method $(S)$} \\
\hline & \multicolumn{2}{|c|}{2017 season } & \multirow{2}{*}{ Means (A) } & \multicolumn{2}{|c|}{2018 season } & \multirow{2}{*}{ Means (A) } \\
\hline & NFT * & SSC** & & NFT * & $\mathbf{S S C}^{* *}$ & \\
\hline & \multicolumn{6}{|c|}{ Vase life (days) } \\
\hline Control & 10.33 & 9.67 & 10.00 & 11.00 & 10.00 & 10.50 \\
\hline Glutamine & 11.33 & 10.33 & 10.83 & 11.67 & 10.67 & 11.17 \\
\hline Methionine & 10.67 & 10.33 & 10.50 & 11.33 & 10.67 & 11.00 \\
\hline Phenylalanine & 12.67 & 11.67 & 12.17 & 12.67 & 12.33 & 12.50 \\
\hline Proline & 11.67 & 11.33 & 11.50 & 12.33 & 11.33 & 11.83 \\
\hline Means (S) & 11.33 & 10.67 & & 11.80 & 11.00 & \\
\hline \multirow[t]{2}{*}{ LSD at $5 \%$} & $S=0.57$ & $\mathrm{~A}=\mathbf{0 . 5 5}$ & $\mathrm{AS}=\mathbf{0 . 8 6}$ & $S=0.50$ & $A=0.70$ & $\mathrm{AS}=0.96$ \\
\hline & \multicolumn{6}{|c|}{ Total chlorophyll content (SPAD unit) } \\
\hline Control & 50.33 & 51.67 & 51.00 & 51.67 & 52.67 & 52.17 \\
\hline Glutamine & 53.67 & 54.67 & 54.17 & 53.33 & 56.33 & 54.83 \\
\hline Methionine & 53.00 & 55.00 & 54.00 & 53.33 & 56.00 & 54.67 \\
\hline Phenylalanine & 55.67 & 57.67 & 56.67 & 54.67 & 58.67 & 56.67 \\
\hline Proline & 54.33 & 56.33 & 55.33 & 55.33 & 56.67 & 56.00 \\
\hline Means (S) & $\mathbf{5 3 . 4 0}$ & 55.07 & & 53.67 & 56.07 & \\
\hline LSD at $5 \%$ & $S=1.03$ & $A=0.82$ & $\mathrm{AS}=\mathbf{1 . 3 9}$ & $S=1.31$ & $A=1.08$ & $\mathrm{AS}=\mathbf{1 . 8 0}$ \\
\hline
\end{tabular}

$* \mathbf{N F T}=$ Nutrient film technique and $* * \mathbf{S S C}=$ Solid substrate culture 


\section{CONCLUSION}

Considering the effects of amino acids under both soilless culture methods on growth and flowering of rose plant (cv. Red Dino), phenylalanine can be used as foliar application at $200 \mathrm{ppm}$ to enhance the productivity of rose under soilless culture especially solid substrate culture in open system culture.

\section{REFERNCES}

Abd El-Aziz, N. G. and Balbaa, L. K. (2007). Influence of tyrosine and zinc on growth, flowering and chemical constituents of Salvia farinacea plants. J. Appl. Sci. Res., 3(11): 1479-1489.

Abou-Hadid, A. F.; Zayed, A.M.; El-Behairy, U.A. and El-Beltagy, A.S. (1989). A comparison between nutrient film technique (NFT) and soil for tomato production under protected cultivation in Egypt. Egypt. J. Hort., 16 (2): 111-118.

Analytical Software (2008). Statistix Version 9, Analytical Software, Tallahassee, Florida, USA.

Burrage, S.W. (1992). Nutrient film technique in protected cultivation. Acta. Hort., 323:23-38.

Davies, D. D. (1982). Physiological aspects of protein turn over. Encycl. Plant Physiology. New Series, 14 A (Nucleic acids and proteins: structure biochemistry and physiology of proteins). 190-288Ed., Boulter, D. and Par.

El-Awadi, M.; El-Bassiony, A.; Fawzy, Z. and ElNemr, M. (2011). Response of snap bean (Phaseolus vulgaris L) plants to nitrogen fertilizer and foliar application with methionine and tryptophan. Nat. Sci., 9: 87-94.

El-Ghamry, A. M.; Abd El-Hai, K. M. and Ghoneem, K. M. (2009). Amino and humic acids promote growth, yield and disease resistance of faba bean cultivated in clayey soil. Australian J. Basic and Appl. Sci., 3(2): 731-739.

Gomez, K. A. and Gomez, A. A. (1984). Statistical Procedures for Agricultural Research. John Wiley \& Sons Inc., Singapore 680.

Gudin, S. (2000). Rose: genetics and breeding. Plant breeding. Reviews, 17: 159-189.

Khan, S.; Yu, H.; Li, Q.; Gao, Y.; Sallam, B. N.; Wang, H.; Liu, P. and Jiang, W. (2019). Exogenous application of amino acids improves the growth and yield of lettuce by enhancing photosynthetic assimilation and nutrient availability. Agronomy, 266 (9): 2-17.

Khattab, A. S.; Abou El-Saadate, E. and Al-Hasn, K. (2016). Effect of glycine, methionine and tryptophan on the vegetative growth, flowering and corms production of gladiolus plant. Alexandria Sci. Exchange J., 4 (37): 647-659.

Khosh-Khui, M. and Teixeira da Silva, J.A. (2006). In vitro culture of Rosa species. In: Teixeira da Silva, J.A. (Ed.), Floriculture, Ornamental and Plant Biotechnology, Advances and Topical Issues, vol. 2. Global Science Books, Ltd., UK, pp. 516526.

Mahdi, S. A. and Saeed, A.A.J. (2019). Effect of tryptophan and phenylalanine on some biochemical components and floral traits of gerbera (Gerbera jamesonii L.) cv. 'great smoky mountains. Plant Archives, 19 (1): 1051-1056.

Maggio, A.; Miyazaki, S.; Veronese, P.; Fujita, T.; Ibeas, J. I.; Damsz, B.; Narasimhan, M. L.; Hasegawa, P. M.; Joly, R. J. and Bressan, R. A. (2002). Does proline accumulation play an active role in stress-induced growth reduction. Plant J., 31: 699-712.

Markwell, J.; Osterman, J. C. and Mitchell, J. L. (1995). Calibration of the Minolta SPAD-502 leaf chlorophyll meter. Photosynthesis Research, 46: 467-472.

Nicola, S.; Hoeberechts, J. and Fontana, E. (2005). Comparison between traditional and soilless culture systems to produce rocket (Eruca sativa) with low nitrate content. Acta Hort. 697: 549-555.

Paciorek, T.; Zazímalová, E.; Ruthardt, N.; Petrásek, J.; Stierhof, Y.D.; Kleine-Vehn, J.; Morris, D.A.; Eman, N.; Jürgens, G. and Geldner, N. (2005). Auxin inhibits endocytosis and promotes its own from cells. Nature, 435: 12511256.

Pareek, N. K.; Jat, N. L. and Pareek, R. G. (2000). Response of coriander (Coriandrum sativum L.) to nitrogen and plant growth regulators. Haryana J. Agron., 16(1\&2): 104- 109.

Sewedan, E. and Osman, A. R. (2014). Influence of diphenylamine and ascorbic acid on the production of Dendranthema grandiflorum, RAM. Life Sci., 11(9): 846-852.

Walter, G. R. and Nawacki, E. (1978). Alkaloid Biology and Metabolism in Plants. Planum, press, N.Y.pp.152.

Yong, J. W. H.; Letham, S. D.; Wong, C. S. and Graham, D. F. (2014). Rhizobium-induced elevation in xylem cytokinin delivery in pigeon pea induces changes in shoot development and leaf physiology. Funct. Plant Biol., 41: 1323-1335. 